\title{
Hunger Habitus: State, Society, and Starvation in Twentieth-Century Bengal
}

\author{
Janam Mukherjee
}

Ryerson University

\begin{abstract}
This article offers a brief summary of the complex factors leading to the famine in Bengal in the 1940s and discusses its longer-term impacts - the afterlife, so to speak- of famine. This episode of starvation claimed as many as five million lives in Bengal, and had long lasting social, political, and economic consequences. Several different paradigms emerged that impacted the socio-political landscape of Bengal in the midst of the famine. Famine studies often focus on causality and on peaks of starvation deaths. However, periods of mass starvation such as the famine in Bengal do not simply end when mass starvation ends. Rather, famine inscribes itself into a famine society in elaborate fashion, impacting post-famine societies in abiding ways for generations to come.
\end{abstract}

Keywords: India, colonialism, gender, political economy, famine, culture.

$\mathbf{T}$

he insistence on causality as a primary (and at times even exclusive) focus in famine studies often distorts the complexity of famine as a multivalent human event. The death of millions of people in a most inhuman manner-through the absolute deprivation and the relentless torture that famine represents-cannot be settled by isolating individual culprits or by analyzing structural factors. Famine represents a limit situation that if studied closely and minutely as an unfolding event, reveals the anatomy of power from top to bottom in kaleidoscopic dimensions. For this reason, I detail the course of the famine in Bengal by examining the political, economic, governmental, and social factors that contributed to mass starvation in this region during the mid-twentieth century (see Mukherjee).

In what follows, I will first summarize the complex factors leading to famine in Bengal, a populous province on the eastern front of British rule in India, the earliest region of South Asia colonized by the British. I will then extend the analysis to a discussion of the longer-term impacts of faminethe afterlife, so to speak, of this episode of starvation that claimed as many as five million lives in Bengal. In this latter exercise, I hope to demonstrate that famine studies would do well to move beyond a narrow focus on famine as a circumscribed historical event, and historians would do well to move beyond analyses of famine that focus exclusively on causality. Periods of 
mass starvation such as the one Bengal went through in the 1940s do not simply end when mass starvation ends. Rather, famine inscribes itself into a famine society in elaborate fashion, impacting post-famine societies in abiding ways.

\section{THE FAMINE}

On 3 September 1939, when England declared war on Germany, it also declared war on behalf of its far-flung empire. Subsequently, the idea of Total War began to underwrite all domestic and colonial policy. Though an attack by Germany on India was highly improbable, large-scale mobilization in India began immediately. An air raid precaution (A.R.P.) service was established in all cities of Bengal, which, together with the Civic and Home Guards, amounted to an ad hoc militia of more than 200,000 by 1943. Mock bombings, complete with phosphorous bombs, ambulance services, and corpse disposal crews, were staged throughout Calcutta, the capital city of Bengal, and the colonial economy was quickly retooled for wartime production. Meanwhile, the Indian National Congress (INC), the country's primary nationalist organ, withdrew from participation in colonial governance, protesting that it had been forced into Britain's war. Without the participation of the INC in Britain's experimentation with democracy in India, much of the country reverted to "emergency rule," which allowed colonial authorities to wield power with especially authoritarian zeal during the entire course of the war. India, in this sense, amounted to an occupied nation for the duration of World War II.

When Japan entered the war in December 1941, and Singapore and Burma fell just a few short months later, Bengal became the front of the Axis/Allied conflict in Asia, and Calcutta became the main source of supplies in a war against a formidable enemy. Calcutta also became a prime target for further Japanese advance, which bred considerable administrative unease in the former colonial capital. The British were shocked by the sound defeats they were dealt across southeast Asia and dug their heels into Bengal with particular resolve. Calcutta was now of paramount geopolitical importance to the British Empire, and its potential loss to Japan could not be countenanced. The call went out for all hands on deck, and the Calcutta population was goaded into reluctant mobilization. Indian residents of Calcutta responded in less than patriotic ways, however: those who had roots outside the city, the middle class, mostly caste Hindu gentry, began to flee in large numbers, while those who had no village to retreat to - the poor, and the working classes - treated A.R.P. drills with disregard, and at times open disdain (WBSA W-72/41). 
As the native quarters were becoming ghost towns, the city was filling up with British and American troops, and the factories that supplied the war machine kicked into overdrive. Subsequently, the need for labour pressed hard on industrialists, who were now turning record profits in war-related industries. Labourers were recruited from the far reaches of Bengal's impossibly vast hinterland to keep the supply train running. By this time, the province of Bengal had been labelled a "dangerous area," and colonial officials themselves were making plans to move their families out of harm's way. Whereas the rhetoric of defence escalated, military protection of the all-important city of Calcutta remained minimal at best, with only ad hoc measures taken to thwart a Japanese attack. The plan that the colonial government came up with-in lieu of actual military preparationamounted to a scorched earth campaign in Bengal. This scheme of "Denial," as it was called, ${ }^{1}$ would have disastrous consequences for the people of the entire region.

The first measure of the "Denial Scheme" was to confiscate all "surplus" rice in coastal districts so that the Japanese could not appropriate it in the event of an attack and a land-march on Calcutta. To this end, the British government agents, backed by law enforcement and the military, went into the countryside and snatched up all the rice that could be found, paying whatever price they deemed appropriate, and wreaking chaos on existing market structures in the process. No real effort was made to establish which rice was "surplus" and which rice was essential, and as such, the scheme appeared to the people of Bengal to be open looting. The rice was to be used to feed labour forces in Calcutta, but much of the confiscated rice seems to have been hoarded in corporate and government warehouses, even while starvation in Bengal began to mount. Already, by April 1942, the price of rice had risen dangerously, and there was distress-and even starvation-in both the city and the countryside. The Denial Policy upped the ante, putting further pressure on prices, disorganizing the traditional market system, and alerting an already uneasy population to the State's mounting anxiety.

After "rice denial" the British colonial government moved on to a scheme of "boat denial." The idea here was to deny potential Japanese landing forces the opportunity of appropriating local conveyance in the event of an advance on Calcutta. The delta of Bengal is one of the most complex waterways in the world, and the "country-boats" of Bengal represented the essential form of transport across much of the region. During the Denial schemes, in the

\footnotetext{
1 This official policy, conceived by the War Cabinet in London, was intended to deprive possible Japenese invading troops of what they might acquire in the event of a naval landing in coastal Bengal and a subsequent march to the industrial city of Calcutta. The Denial Policy was implemented through government and military channels.
} 
period of a few short months, a total of more than 46,000 boats were requisitioned (for military purposes), sunk, destroyed, or otherwise removed from service, crippling the riverine economic infrastructure of deltaic Bengal (Famine Inquiry Commission 26). As life in the districts began to deteriorate without local transport, those who had fled Calcutta months earlier in fear of Japanese attack began to straggle back into the city in search of increasingly scarce resources. Accordingly, the needs of the city, already serving as a war base for tens of thousands of Allied soldiers, escalated still further. It was at this time that war came home to Calcutta.

On 20 December 1942, Calcutta was bombed for the first time by the Japanese. According to official reports, the damage was "slight," 2 but panic gripped the city. Most alarmingly, rice merchants and large holders of stocks of rice fled the city for safer harbours-even while the colonial government worked to keep the war machine functioning. Concerned about access to supplies to feed industrial labourers and the military in and around Calcutta, government agents broke into shuttered private warehouses and requisitioned all the rice they could find (Testimony of L. G. Pinnell, Nanavati Papers 553). Two thirds of the available stocks in Calcutta were summarily seized; in the process, the influential and well-connected Indian merchant class of Calcutta was deeply estranged from the colonial authority. The trade system from root to branch was thrown into complete disarray, and as prices skyrocketed, more and more supplies found their way into the thriving black market. In Calcutta, as rice markets became increasingly volatile, government and industrial interests descended again and again on the countryside to raid it of rice and paddy 3 to offset the uncertainty of rice supplies in the city. The military presence in Calcutta needed to be maintained at all costs.

As conditions in the countryside grew ever more ominous, middle-class Bengalis who had fled the bombings in Calcutta now returned to the city to parlay their influence and status into stockpiles of rice-their entitlement thus putting increased pressure on rice markets in the city. Close on the heels of the returning gentry was a tidal wave of starving villagers who began to

${ }^{2}$ Official instructions promulgated to minimize panic after air raids stated: "where necessary to publish any mention of damage the general terms 'slight,' 'moderate,' and 'heavy' or synonyms of these will be used" (WBSA, Home Political File W-296). Newspapers accordingly reported air raid damage to be "slight" ("Calcutta's First Raid").

3 Paddy is rice in the husk, before being milled. Although the paddy can be stored much longer than milled rice, it is expensive to transport and so was often left at the place of purchase, and thus removed from the open market. Records exist indicating the amount of rice that was moved to Calcutta but not the amount of paddy that was purchased and withheld from the market in the countryside. 
crash onto the shores of Calcutta by May 1943. They came naked or draped in rags and filled the lanes and by-lanes of the city with their broken bodies, human skeletons uttering plaintive moans. Despite extraordinary measures by the colonial state to stem the influx of famine refugees and to censor the inconvenient truth of their wretched arrival in the city, the hunger-and indeed starvation - that had been haunting the rural districts of the region for some years could no longer be denied. In August 1943, Calcutta's premier English newspaper, The Statesman, defied a censorship order to publish a photo essay of starvation on the streets of the city, and the "Bengal Famine of 1943 " came into usage.

\section{CAUSALity}

In this brief summary, the centrality of colonial policies related to the war in Asia is paramount to understanding the course of famine. War created the conditions for an authoritarianism in Bengal that justified extremely predatory economic practices that threw rice markets into chaos and created the conditions for runaway inflation. In addition, according to the calculations of war, priorities were set that greatly disadvantaged those not seen as directly involved in the war effort-namely, the rural poor, who, it might be said, became a kind of "collateral damage" during the famine. War in a colonial setting, moreover, could be conducted with a particularly strong hand and with a pronounced disregard for the native population. While in Britain there had been provisions for rationing and public health since the very commencement of the war, in colonial India, few, if any, precautions were taken to shield the population from the entailments of a wartime economy. In colonial India, the entire governmental apparatus could be fashioned according to the prerogative of Total War without concern for how this fashioning would impact the colonized population. We thus see a dovetailing of colonial and martial ideologies in Bengal at the crux of the massive starvation that erupted in 1943.

One can identify central actors and specific decisions with direct relevance to an analysis of famine in Bengal. A relatively recent focus of such an investigation is Winston Churchill (see Mukerjee). Churchill, a staunch defender of colonialism, hated the Indian National Congress and all discussion of independence for India. He also repeatedly scuttled calls for the import of food into India at the crucial juncture when prices were skyrocketing in Bengal. Beneath Churchill were a host of colonial officials, who through active malice or idle disinterest failed to stem the escalating material distress of the people of Bengal just prior to 1943. From the Viceroy on down to the most local officer, concern for the wretched masses of India was tepid and often laced with a Malthusian fatalism, energized by social 
Darwinism. As the starvation of the poor in Bengal did not prove a threat to the colonial regime or to the British war effort, it was almost completely ignored at every level of colonial governance.

But apart from the crimes of commission, the historical record is replete with evidence not only of venality and culpability in relation to the famine in Bengal but also of the sheer incompetence of the colonial state. Far from establishing a hegemonic presence in India, the colonial state, as late as 1943, had little knowledge of the local population and limited capacities of governance or management. This leant a persistent aspect of confusion, as well as overreach, to the problem of executing wartime policies. The defeats of World War II in Asia had served to demoralize spirits further. Miscommunications, petty squabbling, and trained indifference defined a colonial administration in total collapse. In sum, it might be said, the colonial government had neither the will nor the capacity to contend with the farreaching breakdown of order that the famine in Bengal represented.

What we see in Bengal in 1943, however, cannot be explained by merely examining the enactments of colonialism and war. There were clear indications of chronic hunger, and even starvation, in Bengal that went almost completely unheeded. We must also look to the self-interest of colonial and colonized actors. While the extent of the impoverishment of Bengal's rural masses can be traced to the colonial economy, the invisibility of the poor within the colonial society also must be closely considered. Evidence of acute hardship and even starvation had been reported in rural districts of Bengal as early as 1934 (see Mitter). By the end of that same decade, many small tenants had lost their lands to unscrupulous money lenders and were already insolvent. Meanwhile, in Calcutta, middle-class, white-collar workers were increasingly insulated from the miseries of the rural poor. Politics, elite society, and even nationalism most often failed to address the poverty that was hollowing out the countryside, and rigid caste and class distinctions defined a partition of concern that rendered the hunger of millions invisible to those enjoying relative prosperity. When, in 1942, Gandhi fasted in the name of the "privations of the poor millions," a "Leaders Conference" was called in Delhi. Many of the scions of Indian industry and politics attended to express their support for Gandhi, but none made any mention whatsoever of Gandhi's concern about the material welfare of the now starving population.

In fact, when we look beyond colonialism and its relation to famine in Bengal, we find a class of Indian capitalists who themselves were deeply invested in Calcutta's wartime economic boom, making fantastic profits in textiles, armaments, and other manufactured goods. They deeply imbricated themselves into the colonial state apparatus and peddled influence far and wide in order to maximize their fortunes. During the war, these interests repeatedly partnered with government and military authorities to ravage 
the Bengal countryside in the quest for rice. A conflict between the government and Indian owners of rice mills also had a great impact on rice supplies (Testimony of Representative of the Bengal Rice Mills Association, Nanavati Papers 1211). As industrial interests were amassing their stockpiles, white-collar workers in Calcutta began to hoard. In short, the extent to which the social structure of Bengali society contributed to famine is an interesting subject, one that has important implications even today, with large sectors of Bengali society still on the margins of survival, while remaining all but invisible to priviledged sectors of society.

If one looks at how famine unfolded, many different causal factors can be identified. What is more, the architecture of not only the colonial state but also of the Bengali society and economy is revealed in stark relief. If we take the four factors outlined here into account-colonialism, war, capitalist profiteering, and existing structures of inequality-we begin to approach a better understanding of the causes of the Bengal famine. We also discover more about the anatomy of colonial rule, the ideological mania of total war, unfettered capitalism, and the structural mechanisms of Bengali society that mask the suffering of the poor. The interplay of these factors is extremely complex and tortured, and they are far from exclusive. Armatya Sen's work on the Bengal Famine of 1943 highlighted the economic factors from a theoretical standpoint. There were also environmental factors (see Iqbal) and international factors outside of colonialism (such as the blocking by the USA of UNRRA funds to Bengal in 1944) that might help to assess the causes of the Bengal famine (see Venkataramani). In fact, famine represents a unique lens for examining social, political, and economic structures at large, revealing the mechanics of a given social order in deathly relief.

\section{IN THE WAKE OF FAMINE}

It is here that many studies of famine tend to conclude. Famine is understood as a delimited disaster: its causes are assessed, remedies are discussed, and it is often left at that. Catastrophic famine, however, cannot be understood as a historically circumscribed episode with a beginning, an apex, and a neat conclusion. Rather, famine is a historical event that has very long legs. An intense period of starvation and death from disease, like that which Bengal endured in the 1940s, continues to affect the lived reality of famine-stricken societies for many years to come, with impacts on a people's political and social realities that can extend for generations.

Given that famine does not end when starvation abates, I move beyond questions of causality to questions of longevity. Famine, while stemming often from military occupation, colonialism, and foreign rule, might be said to represent a kind of "occupation" with which famine societies continue to 
struggle after starvation is brought under control. The sheer magnitude of famine becomes mapped onto the collective psyche of a surviving population, and famine transforms societal structures in abiding ways. Hunger remains a persistent spectre, a societal haunting that is inflected in the ongoing collective experience of post-famine societies. This is especially true in Bengal, a region of the world that has grappled with famine throughout its modern history, and where acute hunger, malnutrition, and even starvation continue to plague those on the economic margins. In Bengal, famine is written deeply into the societal script and continues to reverberate distinctly a full seven decades later. In public discussions on famine in Bengal, I have often posed the question of whether or not the Bengal famine ever did come to an end. The question is relevant, as hunger and material deprivation continue to plague the poor in Bengal, and the profound collective experience lives on in memory, art, and intergenerational discourse. For the British, on the other hand, marking an end to the famine in Bengal took on great political importance.

In 1943, when famine in Bengal finally came to wider public notice, it created something of a scandal and embarrassment to the brokers of power-locally, nationally, and internationally. How could it be that Britain's great "civilizing mission" in Asia had gone so wrong? The United States, jockeying throughout the war for geopolitical advantage over Britain in Asia, touted colonialism as the moral scourge of European hegemony. Famine at the heart of empire served this rhetorical purpose well. The British, who had been desperate to keep the conditions in Bengal from the front pages of newspapers, shifted into full damage control mode when the news could no longer be suppressed. Bodies of the starving were rounded up from the streets of Calcutta by force and warehoused in bleak death camps on its outskirts, where they could be hidden from public view. High profile relief campaigns were undertaken by the British military and splashed across international newspapers. By the end of 1943, even though mortality rates were on the rise, Britain strove to call a quick end to famine to stem its own diplomatic bleeding on the international stage (Sen 200-02). Famine in Bengal was simply not consistent with the moral claims of an empire at war. Meanwhile, in Bengal, many of the elite Indian class, for varying reasons of self-interest, were happy to follow suit. The ruling party, at that time the Muslim League, was eager to declare victory over famine in order to legitimize its efforts at remediation, while opposition parties were happy to call an end to famine because they well knew that a "second famine" (which could have been declared at any moment at least until 1946) would destroy the ruling party's claims of having ended famine. In a more general sense, Bengal had grown weary of death, and those with the means to move forward wanted to leave famine behind. 
Famine, however, did not simply slink into a cave like some sad dragon, but continued to take a massive toll, hammering a devitalized population deeper into uncharted despair. Death and dislocation by hunger had altered the very demographics of the region, with whole villages wiped out or abandoned and many millions on the move. Malaria, smallpox, and other epidemic diseases were making fast work of the depleted population, and several million would die even after the dreadful year 1943 had been put to rest. By 1944, however, other dramas took centre stage, and the moans and meanderings of the devastated underclasses fell on deaf ears. With the war seemingly winding down and independence for India expected on the near horizon, famine (as catastrophe now survived) was bandied about for political gain, ladening an already rancorous debate with the weight of several million destroyed bodies. In this sense, for many of the Bengal elite, once widespread starvation had been contained, famine became merely a tool of power-a rather cynical means of mobilizing constituencies and winning popular support. During the entire period of starvation, the political establishment of the region had been deadlocked in bitter rivalry. With ongoing material deprivation and death from starvation and disease, famine was an extremely cheap and easy way to tar one's political opponents. In particular, blame for famine was enthusiastically slung back and forth between the Hindu Mahasabha and the Muslim League, weighing down already bitter debates with the immensity of famine deaths. Famine thus intensified Hindu/Muslim tension in Bengal at an extremely critical juncture.

For the almost exclusively Hindu middle class of Bengal, sandwiched precariously between those who were damned and those who sat in privileged denial, life was harrowing, anxious, and uncertain. This Hindu middle class was positioned between a mass of wretched misery and the competing cabals of self-serving patricians who clung to what they held in terms of resources, influence, and "priority" with a sometimes ruthless resolve, while crippling scarcity continued to make life bitter well into 1946 and beyond. The plight of Bengal's middle class during the famine fostered a congealing of Hindu identity that had lasting, and ultimately, pernicious results. The sufferings of the middle class became easily equated with the claim of disproportionate suffering of Hindus in general, particularly in the context of a Muslim League-dominated Ministry. Government relief for the poor was considered inappropriate for middle-class Hindus because of dietary taboos (upper-caste Hindus will only eat food prepared according to certain caste restrictions, which relief kitchens did not enforce), and as such, it was resented as biased. Moreover, as most of the impoverished agriculture workers, particularly jute planters in eastern Bengal, were Muslims, the famine exacerbated the politically expedient equation of class and religious community. Government relief for the rural poor could be touted as "Muslim relief" by opposition parties, while relief for the middle classes could be 
coded as "Hindu." The claim of social difference, long embedded in the sociopolitical structure of the region, was increasingly lodged in a biopolitical struggle for survival. At length, the Hindu Mahasabha, while distributing relief almost exclusively to the "middle classes," was able to gain a populist foothold throughout Bengal that all previous efforts to consolidate a popular Hindu political front had failed to do-even while the Bengal government, with substantial help from the Government of India and the military, could claim its dedication to assisting the Muslim lower class majority.

It should come as no surprise that further violence, anarchic and annihilating, finally exploded in August of 1946 at the congested and contentious urban core of Bengal in the city of Calcutta. The Calcutta riots, which saw Hindu-Muslim violence on a scale never before witnessed on the subcontinent, cost the lives of perhaps 10,000 people in the former colonial capital, with as many as 200,000 dislocated. ${ }^{4}$ These riots provided the initial spark for the further more apocalyptic Hindu-Muslim violence that accompanied the partition of British India. From where did all that sudden, life-annihilating hatred come? Although these same riots have most often been interpreted through the narrow lens of communalist manipulations, I argue that the Calcutta riots, although distinct from the annihilating structural violence of famine and war out of which they emerged, have to be read from within the context of a cumulative violence that began with chronic, multi-generational poverty compounded by war, and brought to a catastrophic head in devastating famine (Mukherjee 209-34). The riots in Calcutta refracted the complex ruin of Bengal in violent colours and with novel forms of cruelty, self-interest, and heartlessness. They did not emerge out of the thin blue sky of manufactured "communalism."

The impact of the injustice and structural violence of famine that characterized Bengal in the 1940s hardly ends there. In late 1946, while the nationalist clouds were rumbling above and scalpels were being sharpened for the vivisection of the subcontinent, an armed agrarian uprising, the Tebhaga Movement, was unfolding across still undivided Bengal. At the bottom, the primary concern was neither partition nor independence, but economic justice. By early 1947, sharecroppers, a group decimated by famine throughout the preceding years, were burning down their landlords' threshing houses, seizing crops, and demanding a fairer share of the fruits of

\footnotetext{
4 The number of those killed is extremely difficult to ascertain. The total number of dead bodies reported to have been processed through official channels was 3,468 (WBSA, Home Political File 351/46 [Part B, IX]). Many of the dead, however, were disposed of in a non-offical manner (stuffed into manholes or burned in buildings, for example). In my work (Hungry Bengal) I have estimated the dead at 10,000 at least. Several hundred thousands were displaced (see Home Confidential, File W-351/46 [Part B, VII], "Activities of the Civil Supplies Department").
} 
their own labour. The intensity and persistence of this uprising has to be understood as a legacy of famine. There could not have been one amongst the peasantry who had not been touched by hunger, and all had watched thousands around them perish of starvation and disease. As such, the experience of famine proved extremely fertile ground for the Communist Party of India (CPI), which had long been struggling to gain a political foothold in Bengal. The Tebhaga movement is often understood to represent the party's first effective stand in Bengal, gaining its first momentum in the context of famine. Although the Tebhaga movement was ultimately crushed, it simmered below the surface for decades to come, energizing the communists' rise and their long rule in West Bengal three decades later.

It was famine that finally brought the Communist Party out of the shadows in Bengal. Prior to the 1943 famine, the party's strategy of a "People's War" to defeat global fascism had gained only tepid support from a beleaguered population in wartime Bengal. In the early 1940s the Communist Party-at the bidding of the Communist International-had vigorously promoted the allied war effort, had acted to rally labour "morale" in and around Calcutta, had argued against labour action during the war, and had even enthusiastically advocated for policies directly linked to the creation of famine, including denial. This policy of complicity with the colonial state garnered little approbation from a skeptical and increasingly despairing public, and the ideological vagaries of the CPI's internationalism won little popular support. By 1944, however, with the end of the war in sight, and the continuation of dire scarcity still breeding widespread anguish, the Communist Party in Bengal began a cultural turn that directly focused on the intractable plight of the rural poor. It was this turn away from an abstract internationalist ideology and toward recognition of material conditions in agrarian Bengal that established the CPI's first popular foothold in the region. In doing so, it also gave the party a largely autonomous scope in organizing across the state; the idioms of the communist movement being heavily entrenched in cultural work specifically related to the famine.

With widespread relief operations set up mostly from Calcutta, Dhaka, and other cities of Bengal, famine also created the conditions for the urban elites of the early People's War movement to "de-class" in the countryside, which gave leftist intellectuals a new perspective of the inequality that had laid waste to the region. A cultural effervescence emerged among young people associated with the Communist Party, who had often been at the front in famine relief operations. This translated into considerable cultural capital that would serve the party well for years to come. The depictions of famine by artists like Chittaprosad, Somnath Hore, and Zainul Abedin (to name a few) became icons of the post-colonial era, and many artists who had directly associated themselves with the CPI became stalwarts of the party. 
In addition, by 1944, the Indian People's Theatre Association, established directly by the CPI, was touring villages and towns, staging trenchant dramas that portrayed the despair and injustice that had wracked Bengal. This novel experiment in folk theatre brought the Communist Party in close contact with the rural poor and created a template for artistic expression informed by social reality. It also won the Communist Party considerable support among the rural poor.

At the other end of the spectrum, the consolidation of capital and the boom in industry that accompanied war-so fundamental to the policies that engendered famine-resulted in lasting political and economic formations that would impact the history of South Asia for decades to come. The exact extent of profits made and the relation of these profits to the immiseration of Bengal is a topic for further research. It is safe to say, however, that fortunes were made among the industrial elite of India and that these fortunes were funnelled into (and became the backbone of) the nationalist movement. With this confluence of political and economic purposes came certain ideological configurations of influence that remain central to the Indian power structure even today. In some definite sense, the rise to power of this class of industrialists and their influence in Delhi were concocted in the crucible of famine. The claim of "priority" in the face of war made by the industrialists of Calcutta was directly linked to the hunger, dispossession, and despair of the countryside. It was during the war (and the famine) that Indian industrialists consolidated the economic and political powers they still wield today. Famine, in this respect, continues to have important entailments in the structural and political makeup of India.

Gender relations in Bengal also went through a radical transformation during this period of war and famine. In Bengal, as elsewhere, the typical picture of famine has most often been a feminized one: an anonymous woman's emaciated face stares dully into a waiting camera lens, her rail thin arm supports a wasted infant who seeks vainly for sustenance from a sunken, withered breast. It is a barren picture of utter hopelessness: both mother and child will surely perish. However, such artists' depictions do not concur with the data. The historical record reveals that women were less likely than men to die of starvation. While I leave the question of why and how women seem to have had a better chance of surviving famine for another time, I analyze below the consequences of the persistent idea that women were the primary victims of famine.

\section{GENDER AND FAMINE}

The most complete picture of differences in mortality based on gender was given in a report published by the University of Calcutta's Department of 
Anthropology in 1949 (Das). This study has long been regarded as one of the most thorough demographic works compiled during the Bengal famine. The survey was meticulously conducted by eleven well-trained field workers and sponsored by the University of Calcutta. It has remained an important primary source for almost all studies of the Bengal famine, including Amartya Sen's, which relies heavily on this work in reconstructing a demographic picture of the class basis of destitution during the 1943 famine. ${ }^{5}$ According to the data gathered, out of every 1,000 dead, 651 were men and 349 were women (Das 93). The 1951 census figures support the gist of these findings, pegging annual female deaths for the decade as a whole at 918 to every 1,000 male deaths (Srimanjari 210). Death, however, was not the only (or perhaps even the worst) victimization that women, as a whole, were perceived to have suffered in the context of famine.

With American and British military troops stationed throughout the Bengal region during World War II, war and famine created the conditions for a booming sex industry in Calcutta that has long been depicted as the ruin of millions of women across Bengal. Hindu nationalist Shyama Prasad Mookerjee and others made great hay of the scourge of prostitution during the war and the famine. Subsequently, literary and filmic representations of the 1943 famine followed suit, making iconic the image of the poor village woman who sells her "honour" for material survival. By 1946, the "protection of women" from the depredations they were said to have suffered during famine became a recurrent rhetorical framework of the Hindu Mahasabha in Bengal. Accounts of women entering into sex work were greatly exaggerated, and the spectre of a "ruined" Hindu womanhood was used as a wedge against the Muslim League Ministry, which had operated government relief. Moreover, by the end of the decade, the idea of women's economic agency had become stigmatized with what might be called the famine-taint of dishonour. In this light, women's new-found engagement in the labour force-a phenomenon that was seen across the world during and after World War II-in Bengal became entangled with a moral suspicion and a patriarchal disdain that lingers today. Famine, it can be said, created the conditions for a heavier patriarchal hand in shaping these perceptions.

\footnotetext{
${ }^{5}$ In his chapter on the Bengal famine in Poverty and Famines, under the subheading "The Class Basis of Destitution," Amartya Sen draws data from three works, the data for two of which were collected post-1943. In introducing the sources of his data, Sen states, "while these two [other] studies were conducted after the famine was over, a study of the destitutes in Calcutta during the famine was carried out in September 1943 by T. Das (1949) . . covering 820 destitute family units" (70). Sen goes on to draw statistics from Das that are fundamental to his arguments.
} 
The 1960 Bengali film, Meghe Dhakka Tara (Cloud Covered Star), by Ritwik Ghatak, has become emblematic of the post-famine, post-partition period. In the opening vignette, the heroine of the story, Neeta, is seen shuffling off to her work wearing broken sandals, demonstrating her family's acute poverty. In subsequent scenes we learn the backstory to Neeta's employment. Her father is past his prime, and her younger brother, an aspiring singer, cannot earn a living for himself, much less for the family. Facing abject destitution, Neeta takes the bold decision to get an office job. Throughout the course of her short career, she suffers repeated humiliations and ultimately is forced to forgo marriage and personal care in the name of group survival. The pressures of her economic stewardship break her in the end, and in the last scene she is seen begging in a sanatorium somewhere in north Bengal. Her entry into the work force is thus portrayed as her undoing-both morally and materially. That the heroine in Meghe Dhakka Tara has long served as a popular representation of suffering womanhood in post-colonial Bengal is a testament to the ways that famine has impacted gendered understanding of economy in Bengal.

\section{CONCLUSION}

Apart from structural and political considerations, the extent to which famine has affected Bengali collective self-understandings and popular culture is a subject for study that may well be inexhaustible. The decades following the famine and riots, and then partition, were a period of intensive change and struggle, and memories of famine and its myriad entailments remain deeply lodged in Bengali hearts and minds. Famine and hunger were central motifs around which creative thought constellated for generations. "Hungry Bengal" - the title of Chittoprasad's compilation of sketches and essays of famine-ravaged Midnapore-became the label chosen by the following generation of writers, painters, and poets who in the 1950s, 60s, and 70s struggled to come to grips with the enormity of the tragedy that had unfolded in the 1940s. The names of many of these artists are as ubiquitous in Bengali households as the individual stories, passed down by grandmothers and grandfathers, and now great grandmothers and great grandfathers. Thus, famine has written a rich text into the culture of Bengal and continues to do so.

In the years that followed acute starvation, famine became a sort of selfconscious banner of the whole of Bengal for generations - a sign under which the province has long laboured. Even today, seventy years later, it is remarkable the alacrity with which youth in Bengal take to conversations about the famine. Few of them have not heard of it, and many of them have a fair understanding of the event and speak about it with a passion and 
indignation that keeps the famine fresh and relevant in modern Bengal. It is obvious that youth have been learning about famine, probably from as early as they can remember - at the foot of some auntie, or grandfather, or parent, or neighbourhood teller, but also from movies, popular reference, music, and art. The means and modes of famine transmission, and the ways that famine continues to impact social, political, cultural, and economic facets of individuals and communities, lay grounds for further research and analysis.

In assessing and analyzing the collective impacts of famine on Bengali society and culture, the work of Pierre Bourdieu comes to mind, in particular, his concept of "habitus," which figures in the title of this paper. In 1990, Bourdieu defined habitus as "a system of acquired dispositions functioning on the practical level as categories of perception and assessment or as classificatory principles [that inform] the organizing principles of action" (12-13). Habitus, in less technical language, might be described as those dispositions of being and communication that are ingrained in any society by their collective experience, collective memory, and collective representation. It is the lens through which a culture views and expresses itself. Habitus informs the way people speak, the way they think, their gestures, and other unconscious representations of self. The collective memory of famine, as I have seen it in Bengal, has created a strong collective memory that has now spanned several generations, becoming a particularly powerful kind of habitus, the hunger habitus. Again, the event of famine in this sense does not end when starvation ends. Rather, famine writes itself deeply into a culture, with a productivity of energies that also promise possible redemption in the face of almost unimaginable loss.

Overall, I argue for a better historical appreciation of the complexity of famine, in terms of both causality and consequences. Perhaps because it had long been thought that famine resulted only from environmental factors, its imbrication in social, economic, and political structures has received relatively scant attention. On the other hand, if we understand famine as a human (all-too-human) event, we are more inclined to examine its considerable complexities. In this mode, famine becomes an extremely important lens through which we can view structures of inequality, political mobilizations that hinge on resource allocation, and many other aspects of structural violence. In sum, the political economy of famine is a key to the understanding of power structures at large. The concurrence of factors, policies, and enactments that deny large sectors of a population the bare means of existence are essential clues in understanding constellations of power that both precede and follow famine. Moreover, in addressing the complexity of famine more rigorously, it is possible to imagine we are redressing-in a small way-the dismissal of the value of human life at the margins. If the study of the death of many millions in Bengal can shed light 
on critical aspects of the structural violence of famine more broadly, it might be seen as some small redemption of lives lost so senselessly and brutally. 


\section{Works Cited}

Bourdieu, Pierre. In Other Words: Essays towards a Reflexive Sociology. Stanford UP, 1990.

“Calcutta's First Raid.” The Statesman, 22 Dec. 1942.

Das, Tarakchandra. Bengal Famine (1943): As Revealed in a Survey of the Destitutes in Calcutta. University of Calcutta, 1949.

Famine Inquiry Commission of India. Report on Bengal. Government of India, 1945.

Ghatak, Ritwik, writer and director. Meghe Dhakka Tara. Chitrakalpa, 1960.

Iqbal, I. The Bengal Delta: Ecology, State and Social Change, 1840-1943. Palgrave Macmillan, 2010.

Mitter, S. C. A Recovery Plan for Bengal. The Book Company, 1934.

Mukerjee, Madhusree. Churchill's Secret War: The British Empire and the Ravaging of India during World War II. Basic Books, 2010.

Mukherjee, Janam. Hungry Bengal: War Famine and the End of Empire. Oxford UP, 2015.

National Archives of India (New Delhi), Nanavati Papers.

Sen, Amartya. Poverty and Famines: An Essay on Entitlement and Deprivation. Oxford UP, 1981.

Srimanjari. Through War and Famine: Bengal, 1939-45. Orient Black Swan, 2009.

Venkataramani, M. S. Bengal Famine of 1943: The American Response. Vikas Publishing House, 1972.

West Bengal State Archives (WBSA), Home Political Files. 